\title{
MEMBANGUN EPISTEMOLOGI KEPEMIMPINAN SPIRITUAL GUNA MEMPERKUAT PENDIDIKAN ISLAM: SUATU TELAAH DISKURSIF
}

\author{
M Samkhan M \\ Program Studi Pendidikan Agama Islam, Universitas Muhammadiyah Malang \\ email: sani19031922@gmail.com
}

\begin{abstract}
The problems in Islamic education today can be said to be confronted in terms of quality and poor cycles. Several studies have resulted in his analysis which has shown that leadership is the most important fact in an effort to change the cycle for the better. Therefore, it is necessary to construct a paradigmatic science, especially in the framework of the epistemology is able to bring strong leadership. This effort is intended to be carried out in developing and strengthening Islamic education with better management and in which there are Islamic values as elan fundament of education management. Where these values can build motivation and work performance that results in two goals, because the process developed is not only aimed at satisfaction and productivity, but also oriented towards values transcendental-eschatological (worship and the pleasure of God). The leadership is a visionary leadership and is able to build effective, efficient and productive organizational processes in conducive learning. This leadership model is none other; spiritual leadership that is able to give birth to the sun in the world of education.
\end{abstract}

Keywords: epistemology, spiritual leadership, Islamic education

\begin{abstract}
ABSTRAK
Problematika dalam pendidikan Islam saat ini bisa dikatakan berhadapan dalam masalah kualiatas dan siklus yang kurang baik. Dari beberapa penelitian telah mengahasilkan analisisnya yang telah menunjukkan bahwa kepemimpinan adalah fakta paling penting dalam upaya mengubah siklus yang lebih baik. Oleh karena itu, perlu adanya konstruks paradigmatik keilmuan terutama dalam kerangka epistemologi yang mampu melahirkan kepemimpinan yang kuat (strong leaderhip). Upaya ini guna dilakukan dalam membangun dan memperkuat pendidikan Islam dengan pengelolaan yang lebih baik dan didalamnya terdapat nilai-nilai Islam sebagai elan fundamen pengelolaan pendidikan. Yang dimana nilai-nilai tersebut dapat membangun motivasi dan performa kerja yang mengahasilkan dua tujuan, karena proses yang dikembangkan tidak hanya bertujuan pada kepuasan dan produktivitas, melainkan juga berorientasi pada nilai-nilai trasendental-eskatologis (ibadah dan keridhaan Allah). Kepemimpinan terebut merupakan kepemimpinan yang visoner dan mampu membangun proses organisasi yang efektif, efisien dan produktif dalam pembelajaran yang kondusif. Model kepemimpinan ini tidak lain adalah kepemimpinan spiritual yang mampu melahirkan surya dalam dunia pendidikan.
\end{abstract}

Kata Kunci: epistemologi, kepemimpinan spiritual, pendidikan Islam 


\section{PENDAHULUAN}

Kepemimpinan merupakan salah satu topik yang sangat menarik dikaji dan diteliti, karenanya dalam hal kajian ini paling banyak diamati dan sekaligus kurangnya dipahami terhadap khalayak dalam fenomena ini. Pemimpin dan kepemimpin salah satu hal sangat urgen dalam kehidupan berorganisasi, bermasyakat, berbangsa dan bernegara. Permasalahnya adalah beberapa orang mempunyai pendapat bahwa lahirnya pemahaman dalam peng-aktualisasian kepemimpinan itu tak dapat dipelajari. Artinya kepemimpinan itu suatu bakat atau kemampuan yang dibawa sejak lahir. ${ }^{1}$ Asumsi ini salah besar, karenanya banyak para peneliti memberikan teori-teori baru dalam konteks kepemimpinan dewasa ini.

Dalam kacamata ontologi prespektif Islam, secara universal manusia sudah pasti mempunyai kemapuan dalam kepemimpinan -khalifah fil ardh- di muka bumi ini². Maka tugas selanjutnya manusia menggali potensi kepemimpinanya dengan tujuan mengabdi untuk kemaslahatan dunia menuju kemaslahatan akhirat. Menurut Baharudin dan Umiarso, Khalifah sebagaimana didefinisikan oleh Ibnu Khaldun memiliki dua tuntutan kemaslahatan dunia dan akhirat. Dalam satu sisi, pemimpin merupakan pengganti kepemimpinan yang mendapat mandat dari langit setelah Rasul tiada. Sedangkan pada sisi yang lain, pemimpin mengatur manusia di bumi yang barang tentu rasionalitas pemimpin harus berjalan dengan kondisi objektif di bumi. ${ }^{3}$

Ditinjau dari sistem filsafat, rumusan kepemimpinan sebagaimana penulis jelaskan di atas, telah mencakup sisi ontologi. Ontologi sendiri sebagai objek pengelolaan yang mana berupa sumber-sumber belajar, lembaga pendidikan, dan hal-hal lain yang terkait. Kalau penulis masukkan dalam konteks pendidikan Indonesia masih banyak lembaga pendidikan yang mutunya masih belum bisa menggembirakan. ${ }^{4}$ Semangat dalam menyelenggarakan pendidikan sangat lah tinggi dengan ditandai banyaknya lembaga pendidikan Islam. Namun, semangat yang tinggi tersebut tidak diimbangi dengan sikap profesionalisme dalam penyelenggaraan sehingga pendidikan Islam di Indonesia mayoritas berada dalam siklus negatif atau lingkaran setan. Artinya, siswa hanya sedikit dan bermutuh rendah, sarana dan prasarana minim, kualitas, profesionalisme guru pun juga rendah,

\footnotetext{
${ }^{1}$ Salah satu dosen FAI UMM sepakat bahwa lahirnya bakat dalam kepemimpinan itu karena gent. diperkuat oleh teori genetis menjelaskan bahwa seorang pemimpin dilahirkan untuk menjadi pemimpin, artinya dilahirkan didunia dengan bakat-bakat kepemimpinan yang dimiliki. Dalam kondisi dan situasi apapun dan dengan keadaan yang bagaimanapun seseorang ditempatkan karena memang sudah ditakdirkan menjadi seorang pemimpin. Istilah "leaders are burned not built" sesuai dengan teori ini, karena menurut teori ini tidak semua orang bisa dan mampu menjadi pemimpin, hanya orang yang mempunyai bakat dan pembawaan turun temurun dari nenek moyangnya. (baca, Novitasari, N., \& Nurani, F. Pemimpin Yang Bersumber Dari Keturunan.)

2 Pramitha, D. (2016), Kajian Tematis Al-Qur'an Dan Hadits Tentang Kepemimpinan. J-PAI: Jurnal Pendidikan Agama Islam, 3(1).

${ }^{3}$ Baharuddin \& Umiarso, Kepemimpinan Pendidikan Islam, (Jogjakarta: Ar-Ruzz Media, 2012), 82.

${ }^{4}$ Azra. A. Pendidikan Islam, Tradisi dan Modernisasi Menuju Milenium Baru, (Jakarta: Logos, 2000); dan Tafsir dalam, Ilmu Pendidikan Dalam Perspektif Islam, (Bandung: Remaja Rosda Karya, 1994)
} 
sehingga mengakibatikan proses pembelajaran tidak efektif, kualitas out put rendah, kepercayaan masyarakat rendah dst. ${ }^{5}$

Sebagain besar dalam perubahan sosial, pendidikan Islam berada dalam lingkaran globalisasi dan modernisasi selalu ditekankan untuk lebih mampu memainkan perannya secara proaktif dan dinamis, salah satunya dengan keprofesionalisme pemimpin intelektualitas dan religiusitas pemimpin. Lazimnya eksistensi pendidikan Islam mampu memberikan kontribusi dan perubahan positif bagi kemajuan dan perbaikan peradaban umat Islam yang dimana peran ini semua tergantung dengan pengelolaan seorang pemimpin. Mengutip pernyataan Edmonds, ${ }^{6}$ sekolah-sekolah yang dinamis senantiasa berupaya meningkatkan prestasi kerjanya dipimpin oleh kepala sekolah yang baik dan pernyataan Hallinger dan Lithwood yang menyimpulkan bahwa sekolah yang efektif senantiasa dipimpin oleh kepala sekolah yang efektif pula. ${ }^{7}$ Dari sini lah penulis menganalisis terdapat hubungan yang signifikan antara kepemimpinan pendidikan yang efektif dengan sekolah yang efektif. Sehingga output dari dua elemen tersebut akan melahirkan pembelajaran atau tujuan yang diingikan dari Pendidikan Islam.

Oleh sebab itu, perlu adanya konstruk paradigmatik keilmuan terutama dari aspek epistemologiknya yang mampu membangun kepemimpinan spiritual ${ }^{8}{ }_{-}$, kepemimpinan yang mengembangkan kecerdasan emosi -executive $E Q-^{9}$ dan powerful leaders ${ }^{10}$. Dari konstruks paradigmatik ini akan melahirkan suatu tatanan pengelolaan sistem pendidikan yang memiliki basis normatif -wahyuistik dan rasionalistik- untuk melahirkan manusia yang sempurna -al insan al kamil- $^{11}$ dengan selalu berpegang teguh pada al-Qur'an dan Sunnah sebagai nilai normatif dan aspek rasionalitas sebagai medium menafsirkan nilai normatif tersebut dan mendialogkan dengan realitas ${ }^{12}$ Sebagai medium menafsirkan nilai normatif tersebut dan mendialogkan dengan realitas. Di mana kedua aspek tersebut (nilai normatif dan rasio) merupakan suatu bentuk kemutlakan pengembangan sistem pendidikan Islam monokotomik pada ranah teoritis-normatif maupun

\footnotetext{
5 Tobroni, T. (2015) Spiritual Leadership: A Solution of the Leadership Crisis in Islamic Education in Indonesia. British Journal of Education, 3(11), 40-53.

${ }^{6}$ Edmonds. R., Some School Work and More Can, dalam Social Policy, 9 (2), 1979, 206-218.

7 Hallinger F. \& Leithwood K., Introduktion: Exploring the Impact of Principal Leadership. School Effectiveness and School Improvement, 1994, 206-218.

8 Umiarso, U. (2018). Kepemimpinan transformasional profetik dalam mengembangkan pesantren di kabupaten jember. Akademika: Jurnal Pemikiran Islam, 23(1), 87-106.

${ }^{9}$ Goleman. D. Working with Emotional Intelligence, Kecerdasan Emosi untuk Mencapai Puncak Prestasi (Jakarta: Gramedia. 2003)

${ }^{10}$ Agustian. A G. ESQ Emotional Spiritual Quotient (Jakarta: Arga. 2001)

11 Dalam prespektif aksiologi memberikan gambaran hasil pengelolaan berupa pencapaian dari tujuan tersebut. Sehingga dari perpaduan epistemologi dan aksiologi dalam kepemipinan akan melahirkan suatu tatanan yang efektif dan efisien. Adapun istilah efektif dan efisien merupakan keterangan yang menjelaskan aksiologi dan epietemologi. Efektif menekankan pada aksiologi, sedangkan efisien menitik beratkan pada epistemologi. Baca; Maya, R., \& Lesmana, I. (2018). Pemikiran Prof. Dr. Mujamil Qomar, M. Ag. tentang Manajemen Pendidikan Islam. Islamic Management: Jurnal Manajemen Pendidikan Islam, 1(02), 291-316.

12 Ilyasin, M. (2016). Epistemologi pendidikan islam monokotomik: menakar manajemen pendidikan paripurna berbasis rasionalistik $\neg$ wahyuistik. At-turas: Jurnal Studi Keislaman, 3(1).
} 
aplikatif-normatif. ${ }^{13}$ Pola kepemimpinan dalam mengelola tersebut pada lazimnya berimplikasi pada tatanan kearifan pengakuan oleh masing-masing otoritas keilmuan yang ada. Sikap ini perlu dibangun terutam dalam lembaga pendidikan Islam sebagai khazanah norma dan nilai pendidikan Islam.

Dari deksripsi analitik tersebut, penulis mencoba untuk mengkontruks diskursus tentang kepemimpinan spiritual dalam mengelola sistem pendidikan yang mampu melahirkan atau dengan kata lain memperkuat pendidikan Islam. Kepemimpinan dalam mengelolala suatu sistem menurut penulis tidak bisa lepas dari suatu tatantanan filosofis yang melatarinya terutama pada kerangka epistemologinya. Oleh karenan itu, tulisan ini mencoba memulai dari epistemologi kepemipinan spiritual yang kemudian bermuara pada orientasi dalam memperkuat pendidikan Islam. Sebab melihat keresahan dalam para pemikir pendidikan Islam telah mencapai titik klimaks sebagaimana yang diungkapkan oleh salah satunya Azra ${ }^{14}$ dan Sri Minarti ${ }^{15}$.

\section{METODE}

Dalam penelitian ini penulis menggunakan pendekatan kualitatif dengan menerapakan studi kepustakaan. Data sendiri akan dikumpulkan melalui pendekatan penelitian kepustakaan. Sedangkan dalam analisis data lebih menerapkan pendekatan hermeneutik yang produktif. Dari semua proses ini lah metode tersebut akan menghasilkan interpretasi baru dengan menafsirkan teks pemikiran filosofis dalam konteks ketika penulis membacanya melalui konstruks hasil dari prespektif para peneliti maupun penulis lainnya.

\footnotetext{
${ }^{13}$ Mahmud, M. E. (2012). Motif Penyelenggaraan Pendidikan Islam dan Implikasinya pada Pola Manajemen dan Kepemimpinan. Dinamika Ilmu, 12(2).

14 "Menurut Azra, selama kurun waktu lebih dari beberapa dasawarsa sejak berdirinya bangsa Indonesia bebas dari jajahan kolonialisme, dunia pendidikan Islam di Indonesia terutamanya masih dikatakan belum memberikan kontribusi yang signifikan terhadap kemajuan bangsa. Bahkan, pendidikan Islam di Indonesia belum mempu memberikan tanggapan atau jawaban ketika dituntut perannya moral dan mentalitas berbagai persoalan moral dan mentalitas bangsa,..." Baca: Azyumardi Azra, "Rekonstruksi Kritis Ilmu dan Pendidikan Islam” dalam M. Anis, at. al. (peny), Reliugilitas Iptek: Rekonstruksi Pendidkan dan Tradisi Pesantren, (Yogyakarta: Pustaka Pelajar, 1998), xi

15 “...eksistensi pendidikan Islam berada pada posisi determinisme historik dan realisme...satu sisi umat Islam berada pada romantisme historis di mana mereka bangga karena pernah memiliki para pemikir-pemikir dan ilmuan-ilmuan besar dan mempunyai kontribusi yang besar pula bagi pembangunan peradaban dan ilmu pengetahuan dunia serta menjadi transmisi bagi khazanah Yunani, namun di sisi lain mereka menghadapi sebuah kenyataan, bahwa pendidikan Islam tidak berdaya dihadapkan kepada realitas masyarakat industri dan teknologi modern. Hal ini pun didukung dengan pandangan sebagian umat Islam yang kurang meminati ilmu-ilmu umum dan bahkan sampai pada tingkat "diharamkan". Hal ini berdampak pada pembelajaran dalam sistem pendidikan Islam yang masih berkutat pada apa yang oleh Muhammad Abed al-Jabiri, pemikir asal Maroko, sebagai epistemologi bayani, atau dalam bahasa Amin Abdullah disebut dengan hadharah alnash (budaya agama yang semata-mata mengacu pada teks), di mana pendidikan hanya bergelut dengan setumpuk teks-teks keagamaan yang sebagian besar berbicara tentang permasalahan fikih semata". Baca; Sri Minarti, Ilmu Pendidikan Islam: Fakta Teoritis-Normatif \& Aplikatif-Normatif, (Jakarta: Amzah, 2013), 6-7
} 


\section{HASIL DAN PEMBAHASAN}

\section{Epistemologi Kepemimpinan Spiritual}

Epistemologi merupakan bahan yang sangat menarik untuk dikaji karena dari sinilah akarakar pengetahuan maupun teori pengetahuan yang diperoleh manusia menjadi bahan pijakan dalam kehidupan di bumi. Konsep-konsep ilmu pengetahuan yang dewasa ini berkembang pesat beserta aspek-aspek praktis yang dilahirkan dapat dilacak akarnya pada struktur pengetahuan yang telah membentuknya. Dari epistemologi, juga filsafat -dalam suatu kajian ini filsafat modern- terpecah berbagai aliran yang cukup banyak, seperti aliran; pragmatism, positivism, rasionalisme maupun eksistensialisme, dll.

Pada dewasa ini, menurut Arief, kajian mengenai epistemologi sangatlah penting karena saat ini sudah mulai menjangkit semacam kanker epistemologi. Artinya, ini lah menurut Arief telah melumpuhkan kemampuan menilai -critical power-dan mengakibatkan kedunguan dalam berakal -intellectual failure- yang pada giliranya akan menggerogoti keimanan dalam beramal. ${ }^{16}$ Epistemologi merupakan cabang ilmu filsafat yang secara spesifik menggeluti pertanyaanpertanyaan yang bersifat komperehensif dan mendasar tentang pengetahuan.

Dalam prespetif Islam, 'ilmun yang secara harfiah berarti pengetahuan -entitas koseptual yang diketahui- tidak sekedar hanya bermakna secara konkrit empiris, yang semata-mata hasil usaha manusia dalam pengalamannya, tetapi juga bersifat spiritual. Dengan begitu secara terminologi disebut sebagai nadhariyyah al-ma'rifah atau dengan kata lain teori ilmu pengetahuan yang menganalisis dan mengurai tentang hakikat dan ruang lingkup pengetahuan atas dasar-dasar serta postulasi-postulasi yang berkembang serta pertanyaan atas pertanggungjawaban mengenai pengetahuan tersebut. ${ }^{17}$ Ada juga pendapat lain yang lebih menikung mengenai epistemologi. Yang dimana kajian tersebut merupakan cabang filsafat yang membiracakan ilmu dan hakikat ilmu sebagai proses yaitu salah satu usaha dalam pemikiran yang metodik dan sistematik guna melahirkan prinsip kebenaran yang terdapat pada suatu obyek kajian ilmu. ${ }^{18}$ Apakah obyek dalam kajian ilmu itu dan barometer seperti apa dalam mengetahui tingkat jauh dalam kebenaran yang dicapainya dan kebenaran yang bagaimana yang bisa dicapai dalam kajian ilmu, kebenaran obyektif, subyektif, absolut atau relatif. ${ }^{19}$

Epistemologi diaplikasikan guna mengkonstruks teori-teori dalam suatu disiplin ilmu pengetahuan yang mana bisa dipertanggungjawabkan secara rasional dan empiris. Dua elemen inilah dalam tradisi positivistik menjadi syarat utama dalam membangun ilmu pengetahuan; dan

\footnotetext{
${ }^{16}$ Arief, Syamsuddin. Artikel Seminar Epistemologi Islam Mahasiswa Universitas Gadjah Mada tahun 2009.

${ }^{17}$ Dalam kajian ini, secara komprehensif lihat Robert Audy, Epistemology: A Contemporary Introduction to the Theory of Knowledge, (London: Routledge, 2011).

${ }^{18}$ Khojir, K. (2011). Membangun Paradigma Ilmu Pendidikan Islam: Kajian Ontologi, Epistemologi dan Aksiologi. Dinamika Ilmu, 11(1).

${ }^{19}$ Musa Asy'ari, Filsafat Islam: Sunnah Nabi dalam Berfikir, (Yogyakarta: LEFSi, 2001), 65.
} 
sudah pasti; Ahmad tafsir mengungkapkan, keterpaduan rasionalime dan empirisme merupakan satu paket epistemologi untuk melahirkan metode ilmiah -scientific method-. ${ }^{20}$ Melalaui dua elemen ini pulalah otoritatif dan kredibilitas ilmu pengetahuan mampu dibuktifan keabsahanya. Dari beberapa yang banyak digunakan oleh kalangan pemikir yaitu falsifikasi Karl R.popper

Secara epistemologis kepemimpinan spiritual memiliki dua sumber, yaitu sumber normatif dan sumber historis. Sumber normatif sendiri mengurai terkait konsep-konsep kepemimpinan yang berasal dari al-Qur'an dan al-sunnah, sedangkan sumber historisnya yaitu sikap yang telah dicontohkan dengan sempurna oleh Nabi Muhammad SAW. Dengan integritasnya yang begitu luar biasa dan digelari sebagai manusia yang terpercaya -al amin-, Muhammad SAW mampu mengembangkan kepemimpinan yang paling ideal dan paling sukses dalam sejarah peradaban umat. ${ }^{21}$ Bebearapa contoh teori kepemimpinan yang diutarakan oleh para ahli manajemen ternyata telah terdapat pribadi Rasullah SAW. Misalnya empat fungsi kepemimpinan -the 4 roles of leadership- yang dikembangkan oleh Stephen covey. Konsep ini mengorientasikan dan menekankan bahwa seorang pemimpin harus memiliki empat fungsi kepemimpinan; sebagai pemberdaya -empowering-, perintis - path finding-, penyelaras -aligning-, dan panutan modelling. 22

Nabi Muhammad SAW. telah mengaplikasikan keempat fungsi kepemimpinan tersebut dengan sangat baik, sempurna dan berhasil. Walaupun demikian kepemimpinan yang dicontohkan oleh Rasullah SAW. tidak harus menunggu pembenaran dari teori-teori kepemimpinan dan manajemen modern karena apa yang dilakukanya telah terbukti berhasil. ${ }^{23}$ Begitu juga dalam sifatsifat fundamen kepemimpinan yang dikembangkan oleh Warren Bennis; visioner - guiding vision-, rasa ingin tahu -curiosity-, berkemampuan kuat - passion-, integritas -integrity-, amanah -trust-, dan berani - courage-. ${ }^{24}$ Dari semua hal ini, bisa kita kenali dengan kontrusk kepemimpinan spiritual atau kepemimpinan profetik.

Lebih luas lagi, dalam pembahasan normatif sendiri kepemimpinan telah menjadi topik dan pembahasan sejak lebih dari 2000 tahun yang lalu. Sejak histori manusia pertama; Nabi Adam as., sudah dibutuhkan adanya pemimpin yang dapat mengatur hubungan manusia. Nabi Adam as., sudah mendapatkan amanah dari Allah SWT sebagai khalifah atau pemimpin untuk mengatur ekosistem alam semesta ini dengan baik. Sebagaimana tercantum dalam firman Allah SWT (QS.

\footnotetext{
20 Ahmad Tafsir, Filsafat Umum: Akal Dan Hati Sejak Thales Sampai Capra, (Bandung: Remaja Rosdakarya, 2001), 25

${ }^{21}$ Michael H. Hart. 1994. Seratus Tokoh yang Paling Berpengaruh dalam sejarah. Jakarta: Pustaka Jaya, 27.

22 Stephen R Covey, The $8^{\text {th }}$ Habit From Effectiveness To Greatness (London: Simon \& Schuster UK Ltd), 113-114

${ }^{23}$ Muhammad Syafi'i Antonio, Muhammad Saw: The Super Leader Super Manager (Jakarta: PLM, 2007), $18-19$

${ }^{24}$ Warren Bennis, On Becoming a Leader (New York: Addison, 1994), 38-42
} 
Al-Baqarah, 2:30). Dalam ayat tersebut, Allah menggunakan istilah khalifah ${ }^{25}$ yang sangat erat kaitanya dengan kepemimpinan. Dengan katalain, persoalan kepemimpinan telah ada sejak penciptaan manusia dalam rencana Allah SWT.

Nabi Muhammad saw secara jelas menyebutkan soal kepemimpinan dalam salah satu sabdanya;

"Setiap orang di antara kalian adalah pemimpin dan akan dimintai tanggung jawab atas kepemimpinannya. Seorang imam adalah pemimpin dan dimintai tanggung jawab atas kepemimpinannya. Seorang suami adalah pemimpin di tengah keluarganya dan akan dimintai tanggung jawab atas kepemimpinanya. Soal isri adalah pemimpin dan akan ditanya soal kepemimpinannya. Seorang pelayan atau pegawai juga pemimpim dalam mengurus harta majikanya dan ia dimintai tanggung jawab atas kepemimpinanya. ${ }^{26}$

Sementara menurut syekh Islam, Ibnu Taimiyah, mengatakan:

"Urusan memimpin orang banyak adalah satu di antara kewajiba-kewajiban agama yang terbesar, bahkan agama tidak tegak tanpa adanya pemimpin, karena kemashlahatan umat manusia tidak bisa sempurna kecuali dengan bermasyarakat, sebab masing-masing pribadi saling membutuhkan satu sama lain, sedang masyarakat itu tidak bisa harus mempunyai pemimpin "27

Terminologi pemimpin dalam Al-Qur'an menggunakan istilah Khalifah, Ulul al-amri, Imam dan Malik. ${ }^{28}$ Sementara Muhammad Abduh yang terkontaminasi dengan pemikiran Barat, Sayyid Quthb ${ }^{29}$ yang pernah hijrah dalam pendidikannya di Barat dan bersentuhan langsung dengan politik Barat memberikan asumsi bahwa kepemimpinan itu adalah hak bagi orang-orang yang karena amal dan perbuatanya bukan warisan dari keturunan -sudah berbeda lagi dengan pernyataan dalam pendahuluan di atas terkait teori genetis-. Hanya saja dalam penafsiranya Sayyid Quthb tampak lebih menonjolkan pembelaanya terhadap Islam. Hal ini terlihat ketika dia menyatakan bahwa terjatuhnya kaum Yahudi dari kepemimpinanya dan yang berhak untuk menjadi pemimpin adalah umat Islam yang sesuai dengan manhaj -aturan- Allah SWT. Kepemimpinan menurut Sayyid Quthb meliputi pemimpin risalah, pemimpin kekhalifahan, pemimpin shalat dan semua imamah atau kepemimpinan sebagaimana al-Zamakhsyari, Sayyid Quthb mengungkapkan konsep keadilan bagi para pemimpin dan jika pemimpin itu melakukan kazaliman maka lepaslah dirinya dari hak kepemimpinan.

\footnotetext{
${ }^{25}$ Kata Khalifah berarti pengganti atau pemegang otoritas Tuhan di muka bumi, istilah ini dipakai sebagai sebutan bagi pemimpin kaum Muslim setelah Rasullah SAW. wafat, seperti untuk para Khulafa ar-Rasyidin. Para khalifah ini diyakini memiliki otoritas duniawi dan keagamaan. Sedangkan dalam paham teorasi, raja atau kaisar dianggap sebagai perwujudan -titisan- Tuhan, misalnya lagi, kaisar jepang dipercayai sebagai keturunan Dewa matahari dsb.

${ }^{26}$ Sahih Al-Bukhari dari Ibnu Umar ra No. 893,2409, 2558, 2751, 5188, 5200 dan Sahih Muslim dari Ibnu Umar ra No. 4724. HR. Tirmidzi: bab al-Jihad. HR. Abu Dawud: bab al-Imarat dan HR. Ahmad: bab alImam. Baca: Almaktabah Shamillah Bahsun fi Nusus

${ }^{27}$ Ibnu Taimiyah, Pedoman Islam dalam Beragama, (Bandung: CV. Diponegoro, 1967)

${ }^{28}$ Al-Raghib al-Ashfahani, Mufradat Alfaz al-Qur'an, (Damsyiq: Dar al-Qalam, 1992)

${ }^{29}$ Sayyid Quthb, Fi Zilal al-Qur'an, Jilid I, (Kairo: Dar al-Syuruq, Cet. XVIII, 1412 H/ 1992 M), 112-113
} 
Dari konstruks di atas dapat disimpulkan penulis bahwa term yang digunakan al-Qur'an untuk menjelaskan tentang kepemimpinan yaitu khalifah, ulul al-amr, imam dan malik. Adapun penafsiran para ulama atas ayat-ayat kepemimpinan itu terkait dengan latar belakang mufasir, metode, dan corak yang digunakanya. Walaupun pada akhinya menghasilkan penafsiran tentang kepemimpinan yang hampir sama yang pada intinya berpendapat bahwa seorang pemimpin itu wajib menyeru kebajikan, menegakkan keadilan dan menolak kezaliman.

Kata kepemimpinan telah sering kita dengar dan banyak kenal, baik dalam kacamata sosiologik maupun akademik. Namun, ketika istilah kepemimpinan di integrasikan dengan konsep $S Q$ kemudian menjadi istilah leadership $S Q$ menjadi sedikit membingungkan. Selanjutnya dalam tulisan ini, konstruks leadership $S Q$ akan ditafsirkan sebagai "Kepemimpinan Spiritual". Kata spiritual berasal dari bahasa Inggiris yang mempunyai arti kata dasar spirit. Istilah spirit sendiri mempunyai cakupan makna; arwah atau roh, jiwa, semangat, ghaib, moral dan tujuan makna yang hakiki. ${ }^{30}$ Sedangkan dalam bahasa Arab, mempunyai istilah ma'nawi dan ruhani dari segala sesuatu dalam istilah spiritual itu sendiri. ${ }^{31}$

Substansi dari istilah spirit berkembang kata menjadi spiritual dan spiritualitas spirituality- dengan arti bermuara kepada keadilan, kehakikian, dan ruh dengan kata lain bukan sifatnya sementara dan tiruan. Dalam kacamata Islam, dimensi spiritualitas selalu berkaitan dengan realitas Ilahi, Tuhan Yang Maha Esa -tauhid-. Manusia memiliki dua unsur, diantaranya; unsur materian dan spiritual atau yang sering kita kenal unsur jasmani dan rohani. Karakter dari manusia merupakan output dari tarik-menarik antara energi material dan spiritual atau antaran dimensi jasmaniah dengan rohaniah. Spiritual senantiasa menekankan membuat suatu kemungkinan membawa arahan dimensi manusia terhadap dimensi spiritual -keilahian dan ruh-. Dengan cara; menginternalisasi dan memahami sifat-sifatNya, menjalani kehidupan sesuai dengan petunjukNya -huddan- dan meneladani atau meniru perbuatan atau sikap RasulNya. Tujuan dari semua ini yaitu untuk memperoleh ridhoNya, menjadi kekasihNya -wali-. Inilah manusia paripurna atau yang suci dalam keberadaanya membawa kegembiraan bagi penduduk bumi.

Kepemimpinan spiritual merupakan kepemimpinan yang orientasinya membawa dimensi keduniawian kepada dimensi keilahian (spiritual). Tuhan yang sebagai pemimpin sejati yang mempengaruhi, mengilhami, melayani dan menggerakkan hati nurani hambaNya dengan tangan yang sangat bijaksana melalui pendekatan keteladanan dan sangat etis. Dengan begitu kepemimpinan spiritual disebut sebagai berfundamen etika religius. Kepemimpinan yang mampu membangkitkan, mengilhami menggerakkan dan mempengaruhi dengan cara pelayanan yang

\footnotetext{
${ }^{30}$ Oxford Advanced Learners's Dictionary. 1995. Oxford Universuity Press. Hart M.H. Seratus Tokoh yang Paling Berpengaruh dalam sejarah (Jakarta: Pustaka Jaya. 1994), 1145-1146.

${ }^{31}$ Ismail, S. H. (2015). Pembangunan Insan dalam Falsafah Pendidikan Kebangsaan (Human Development in National Education Philosophy). Journal of Human Capital Development (JHCD), 8(2), 83-100.
} 
penuh keteladanan, kasih saying dan ilmplementasi akan sifat dan nilai-nilai ketuhanan lainya dengan tujuan budaya, proses dan sikap kepemimpinan.

Dalam konstruks yang penulis uraikan di atas mengambarkan bahwa persoalan spiritualitas semakin diterima dalam dewasa ini. Dalam kacamata sejarah Islam, spiritualitas telah membuktikan akan kekuatan yang sempurna guna melahirkan individu-individu yang suci, memiliki akhlakul karimah dan integritas yang keberadaanya bermanfaat kepada umat. Sehingga dalam tatanan sosial, mampu membangun masyarakat Islam mencapai ujung peradaban, mempu mencapai predikat khaira ummat dan keberadaanya melahirkan kehagiaan untuk semua -rahmatan lil'alamin-.

Kepemimpinan spiritual bukan saja berarti kepemimpinan yang lepas dari intelektual dan bukan hanya sangat rasional. Melainkan juga harus membersihkan rasionalitas dengan bimbingan hati nuraninya. Kepemimpinan spiritual justru tidak berarti kepemimpinan yang hanya dalam ranah kekuatan ghaib sebagaimana yang kita pahami dalam istilah tokoh spiritual atau penasihat spiritual, melainkan kepemimpinan yang cenderung menggunakan kecerdasan spiritual, ketajaman mata batin. Mengutip pernyataan Nurcholis madjid, intelektualitas tanpa spiritualitas yaitu muspro.

Penelitian dan kajian kepemimpinan spiritual dengan banyak versi peristilahanya yang semakin berwarna dan banyak dilakukan pada dasawarsa ini. Apa yang penulis tulis ini dan juga telah dilakukan oleh para peneliti terdahulu sebagaimana dikemukakan di atas terbukti sangat efektif. Dalam konteks pendidikan Islam dengan berbagai masalah dan persoalan yang menyuguhkan, kepemimpinan spiritual; salah satu solusi paling efektif dalam melakukan perubahan.

Namun jika kita melihat dari banyaknya teori-teori kepemimpinan yang disuguhkan pada saat ini, terdapat dua model dalam kepemimpinan jika dilihat dalam sumber dan tindakan kepemimpinan; kepemimpinan spiritual dan kepemimpinan konvensional. Artinya, kepemimpinan konvensional lazim diterapkan dengan berbagai institusi atau lembaga formal dan sebagaimana disuguhkan dalam literatur-literatur saat ini. Kepemimpinan konvensional menggunakan kerangka berfikir positivistic atau paradigma ilmiah dalam menjalankan peran kepemimpinanya.

Dalam tulisan ini, konstruks kepemimpinan spiritual tidak hanya saja menggunakan rasioanal maupun yang serba supra rasional. Kepemimpinan spiritual cenderung lebih menggunakan atau mengandalkan kecerdasan spiritual -ruhani, ruh, soul, hati nurani- dalam menjalankan kepemimpinan. Sehingga dalam konstruks ini, melahirkan suatu argumen besar -visi dan misi-, spririt atau semangat -etos kerja guna berjihad-, dan syiar yang melahirkan inspirasi, motivasi dan keteladanan bagi pengikutnya. Kepemimpinan yang tetap berpegang teguh akan nilainilai normatif yang dapat dilihat oleh pengikutnya sebagai simbol yang bisa ditafsirkan. Ada 
karakter yang menyatu kuat dalam diri individu; sikap altruistik-humanistik, sikap membangun perilaku konstruktif, dan sikap meningkatkan ketaqwaan serta keimanan kepada Allah. ${ }^{32}$

Ketiga karakter ini jika kalau di integrasikan dengan pernyataan Kuntowijoyo merupakan ouput dari Islam profetik dengan proses trilogi; liberasi, humanisasi dan transendensi yang dimana dihasilkan dari intepretasi QS. Ali Imran:110; mengutip pernyataan Hamid dan Juliansyahzen, prinsip ini merupakan prinsip fundamen dari kepemimpinan profetik. ${ }^{33}$ Menambahkan kembali dari pernyataan Tobroni mengenai karakteristik; diataranya seorang pemimpin dalam kepemimpinannya yang berbasis spiritual maka akan cenderung bersikap; fokus amal saleh, spiritualisme yang tidak dogmatis, bekerja lebih efisien, kejujuran sejati, membangkitkan yang terbaik dalam diri sendiri dan orang lain, disiplin tetap fleksibel, santai dan cerdas, keterbukaan dalam menerima perubahan dan kerendahan hati. ${ }^{34}$

Kendati sikap atau karakter dari pemimpin dalam kepemimpinannya tersebut merupakan wujud sosok muhsin yang mempunyai penghayatan melekat akan kehadiran Tuhan dalam dunia organisasi dan ditafsirkan dalam bentuk tindakkan atruistik ${ }^{35}$. Strategi kepemimpinanya lebih menekankan pada aspek pembentukan tata keorganisasian professional dengan lebih meningkatkan pemberdayaan potensi pengikut dan perilaku mecerahkan iman dan hati nuraninya. Pemimpin tersebut akan melahirkan perilaku kepemimpinanya lewat kesadaran dirinya sebagai insan spiritual yaitu insan yang memiliki kesadaran ketunanan kebaikan melalui amal saleh. Jikalau pemimpin sudah mencapai dalam tingakatan ini, sudah bisa dikatakan pemimpin tersebut telah mencapai kebesaran spiritual individual -individual spiritual greatness-

Dengan begitu, kesadaran dalam ketuhanan yang di tafsirkan dalalm bentuk perilaku altruistik yaitu perwujudan dari sikap ihsan. Ketika diimplementasikan dalam organisasi mempunyai implikasi yang real terhadap tatanan keorganisasian maupun terhadap karakter SDM (sumber daya manusia). Wujud dari ihsan sendiri merupakan internalisasi dari prinsip Islam dan keimanan seseorang agar mampu meraih kondisi yang baik dan ideal dalam menjalani kehidupanya. Seseorang jikalau sudah meraih dalam puncak ihsan, maka mereka akan berada pada situasi tingkat kehidupan yang membahagiakan penuh dengan kerelaan ( $f$ isyat radhiyah). Ihsan akan menggiring umat manusia guna berada dekapan cinta, kasih saying, persahabatan dan

\footnotetext{
32 Umiarso, U. (2018). Kepemimpinan transformasional profetik dalam mengembangkan pesantren di kabupaten jember. Akademika: Jurnal Pemikiran Islam, 23(1), 87-106.

${ }^{33}$ Noor Hamid dan Muhammad Iqbal Juliansyahzen, "Prophetic Leadership in Pesantren Education: Study at Pondok Pesantren Universitas Islam Indonesia," Jurnal Pendidikan Islam 6, no. 2 (27 Desember 2017): 349

${ }^{34}$ Tobroni, T. (2015). Spiritual Leadership: A Solution of the Leadership Crisis in Islamic Education in Indonesia. British Journal of Education, 3(11), 40-53.

${ }^{35}$ Altruistik atau Altuisme; motivasi guna meningkatkan kemaslhatan, kedamaian dan kesejahteraan terhadap orang lain. Baca: Sarwono, Sarlito W. \& Eko A. Meinarno. (2009). Psikologi Sosial. (Jakarta: Penerbit Salemba Humanika). Hlm 123-125. Dan santrock menyatakan bahwa ketertarikan yang tidak egois dalam membantu orang lain juga disebut sebagai perilaku altruistik. Baca: Santrock, John W. Adolescence. Perkembangan Remaja. Edisi Keenam. (Jakarta: Erlangga, 2003), 245
} 
persaudaraan. ${ }^{36}$ Dengan kata lain, kebesaran spiritual terhadap individu akan mengahasilkan bentuk aktualisasi perwujudan ihsan di dalam perilaku keseharianya.

Substansi kepemipinan spiritual guna mengaktualisasikannya dalam proses transformasi sistem ke ranah yang lebih baik dengan berperan membangun potensi sumber daya manusia (libarasi) melawati perilaku alturistik (humanisasi) guna meraih tujuan duniawi dan ukrawi atas dasar kesadaran ketuhanan (transendensi). Proses tersebut akan melahirkan output yang tidak hanya bersifat rasional (dimensi duniawi), tetapi diorientasikan membangun kelembagaan professional melalui sumber daya manusia yang memiliki kesadaran ketuhanan (dimensi ukhrawi atau transendental) guna mencapai kesempurnaan dunia dan akhirat. Esensi tersebut seimbang dengan spirit Nabi Muhammad ketika Hijrah dari Mekkah menuju Yastrib (Madinah).

Pemimpin yang mengimplementasikan gaya kepemimpinan spiritual merupakan pemimpin yang bidimensional. Semua diorientasikan pada dua aspek; raga dan jiwa dan diarahkan pada dua dimensi; keduniawian dan keakhiratan, dan lembaga atau organisasi yang dirintis dengan fundamen ibadah. Kepemimpinan spiritual tersebut akan membawa dimensi keduniawian kedi dimensi spiritual (keilahian); artinya, gaya kepemimpinan yang mengintegrasikan domain profan dengan trasendental.

\section{Reorientasi Pendidikan Islam dengan Menggunakan Kepemimpinan Spiritual}

Seperti penulis deskripsikan dalam pendahuluan, strategi yang paling manjur untuk lebih membangun lembaga pendidikan Islam dengan siklus positif dan merubah siklus negatif lembaga pendidikan islam salah satunya melalui kepemimpinan spiritual -intelektualitas dan religiusitas pemimpin-. Dengan begitu, pemimpin yang mengaplikasikan dua elemen antara intelektualitas dan religiusitasnya yaitu faktor yang cenderung terjadinya suatu perubahan dari lembaga pendidikan yang tidak diminati menjadi berprestasi. Yang dimana terdapat lembaga pendidikan Islam yang baik dan berhasil dalam mewujudkan visi dan misi lembaganya, didalamnya sudah pasti terdapat "orang besar"; orang yang mempunyai konstruks etika religius (nafs al-mutmaninnah, ikhlas dan taqwa). Dalam proses implementasi konstruks ini dalam kehidupan sehari-hari akan mewujudkan orang yang memiliki dedikasi (pengabdian) dan komitmen (kepedulian), rela berkorban, sabar dan berjuang tanpa kenal lelah dan ikhlas. Inilah pemimpin yang mampu menjadi soko guru tegaknya lembaga pendidikan Islam dengan landasan spiritual dalam menjalankan suatu kepemimpinannya. Pemimpin ini lah yang rela memberikan sebagian hidupnya untuk mengembangkan dan memperkuat pendidikan Islam. Mereka berjihad guna pendidikan Islam dengan jiwa dan hartanya. Ini lah pemimpin spiritual dalam pendidikan Islam.

Menurut Qomar, memberikan ciri-ciri dari seorang pemimpin dalam kepemimpinan pendidikan Islam, antara lain: ${ }^{37}$

\footnotetext{
${ }^{36}$ Imam Taufiq, Al-Qur'an Bukan Kitab Teror: Membangun Perdamaian Berbasis a-Qur'an (Yogyakarta:
} Bentang, 2016), 78. 
1. Mempunyai karisma atau wibawa dihadapan manusia atau orang lain (QS. Huud: 91).

2. Memiliki pengetahuan dan kemampuan yang cukup untuk mengendalikan lembaga atau organisasinya.

3. Memahami bahasa dan kebiasaan orang yang menjadi tanggung jawabnya (QS Ibrahim: 4).

4. Memfungsikan keistemewaanya yang lebih disbanding orang lain (QS. Al-Baqarah 2:247).

5. Bermusyawarah dengan para pengikut serta mintalah pendapat dan pengalaman mereka (QS Ali Imron: 159).

6. Bermusyawarah dengan lembut dan kasih saying terhadap bawahanya, agar orang lain simpatik kepadanya. (QS Ali Imron: 159).

7. Bersedia mendengar nasehat dan tidak sombong, karena nasehat dari orang yang ikhlas jarang sekali kita peroleh (QS Al-Baqarah 206).

8. Mempunyai power dan pengaruh yang dapat memerintah serta mencegah karena seorang pemimpin harus melakukan control pengawas atas pekerjaan anggota, meluruskan keliruan, serta mengajak mereka untuk berbuat kebaikan dan mencegah kemungkaran (QS Al-Hajj 41).

Adapun sebagai suatu langkah solusi internalisasi dalam mengamalkan nilai-nilai kepemimpinan spiritual menjadi formula yang dapat diambil dan dijadikan pegangan serta pedoman oleh pengelola lembaga pendidika Islam.

Lembaga pendidikan Islam akan kuat, besar dan dapat bersaing apabila fundamen dalam pengelolaanya mengikuti petunjuk-petunjuk yang ada didalam al-Qur'an dan Hadist. Dengan kata lain, dua dasar ini (Islam) menjadi dasar utama dan nilai operatif dalam pengelolaan lembaga pendidikan yang mulai dari fungsi peramalan (futuristik), perencanaan, pengorganisasian, pengaktualisasian, dan pengawasan hingga pada fungsi evaluasinya atau fungsi tersebut jika dirubah sedemikian mungkin (disederhanakan) dan lazim dikaji menjadi fungsi perencanaan (planning), pengorganisasian (organizing), penggerakan (actuatiang) dan pengawasan (controling) (lihat gambar 1). ${ }^{38}$

Dengan begitu, Islam tetap menjadi rujukan dan sumber utama seperti dalam aspek aksiologi (efektif) maupun dalam ranah aspek epistemologinya (efisen), sehingga dalam proses pengelolaan tersebut akan membuahkan spirit-esensial dalam pengelolaan pendidikan Islam guna meraih tujuan idealitas pendidikan Islam. Fundamen nilai-nilai Islam mampu mengembangkan dan membangun motivasi dan performa kerja yang mengandung dua pengertian atau tujuan, karena pola yang dibangun tidak hanya cenderung dalam tujuan pada produktivitas dan kepuasan, namun juga mengarah pada nilai-nilai eskalogis-transedental (ibadah dan keridahaan Allah).

\footnotetext{
${ }^{37}$ Qomar, M. (2013). Strategi Pendidikan Islam. (Jakarta: Erlangga), 277.

38 Ilyasin, M. (2016). Epistemologi pendidikan islam monokotomik: menakar manajemen pendidikan paripurna berbasis rasionalistik $\urcorner$ wahyuistik. At-turas: Jurnal Studi Keislaman, 3(1).
} 


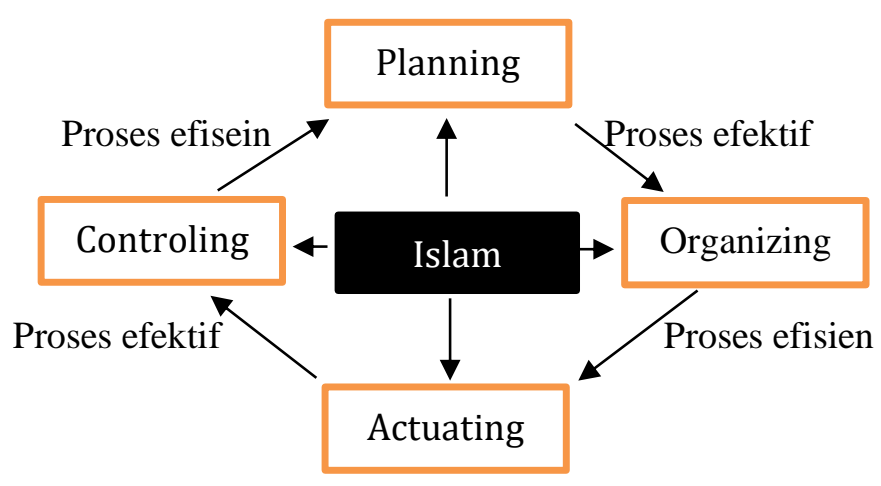

Gambar 1

Lebih spesifik kembali, Azra memberikan gagasan terkait perencanaan pendidikan Islam; perlunya dirombak kembali yang menyangkut struktur kurikulum dan mata pelajaran. Oleh kerena itu, perencanaan dalam pendidikan Islam wajib berdasarkan dua nilai pokok dan permanen, diantaranya; persatuan fundamental masyarakat Islam tanpa dibatasi ruang dan waktu, dan persatuan internasional berdasarkan kepentingan teknologi dan kebudayaan bersama atas dasar nilai-nilai kemanusian. ${ }^{39}$ Artinya, setiap mata pelejaran yang diberikan oleh peserta didik harus memenuhi dua tantangan pokok; pertama, peserta didik diharapkan dapat menguasai ilmu pengetahuan dan teknologi; kedua, penanaman pemahaman ajaran pengalaman ajaran agama yang lebih komprehensif -memahami dengan pendekatan bayani, burhani dan irfani-.

Oleh karena itu semua, dalam semua hal ini ada ditangan seorang pemimpin yang cerdas dalam mengelola. Alih-alih dengan landasan spiritual dalam mengani sistem pendidikan Islam. Dengan berusaha maraih tujuan pendidikan Islam yang berlandaskan kurikulum pendidikan Islam, yang secara ideal berfungsi membina dan menyiapkan peserta didik yang berilmu, berteknologi, berketrampilan tinggi, dan sekaligus beriman dan beramal saleh. ${ }^{40}$

Sementara itu, kalau menggunakan kacamata metodologis, dalam pengelolaan pendidikan Islam guna mencapai tujuan tersebut perlu dilakukan dengan memanfaatkan sumberdaya -entah itu dalam sifat material maupun immaterial- pendidikan Islam yang diimplementasikan oleh seluruh sumberdaya manusia terutama dalam sosok pemimpin. Di sisi lain juga perlu melakukan kerjasama dengan pihak, komunitas atau lembaga lain dengan secara efektif, efisien dan produktif. Dengan kata lain, keterbukaan dalam sisi paradigma, pemikiran dan juga pada sisi praksis-manajerial untuk menjadikan subjek pengelola pendidikan Islam lebih elastis dan dinamis guna meningkatkan mutu pendidikannya. Sikap inklusif cenderung mengarahkan pada keterbukaan dalam memformulakan teori-teori dari luar yang kebetulan ada keseimbangan dengan prinsip dasar manajemen pendidikan terutama nilai-nilai ajaran Islam. Sehingga banyak pada kalangan lembaga pendidikan Islam yang

\footnotetext{
${ }^{39}$ Azyumardi Azra, Esei-Esei Intelektual Muslim dan Pendidikan Islam (Jakarta: Logos Wacana Ilmu. 1998), 7-8.

${ }^{40}$ Sayyi, A. (2017). Modernisasi Kurikulum Pendidikan Islam Dalam Perspektif Azyumardi Azra. TADRIS: Jurnal Pendidikan Islam, 12(1), 20-39.
} 
mengkurung diri dikarenakan merasa "besar dalam tamengnya"; dan tragis pula, sikap menutup (ekslusif) diri tersebut hanya disebabkan oleh ideologi organisasi keumatan yang tidak sefrekuensi dengan organisasi lain. ${ }^{41}$ Artinya, sikap transparansi, toleransi, inklusif dan positif thinking, rendah hati dan optimistik merupakan ouput (nilai-nilai) yang diajarkan Islam guna meraih kesuksan dalam pengelolaan pendidikan Islam.

Adapun menurut Tobroni ${ }^{42}$ peran sosok pemimpin spiritual dalam memperkuat dan mengembangkan pendidikan Islam diantaranya;

1. Pemimpin Spiritual Sebagai Pemimpin Organisasi Pendidikan

Lembaga pendidikan Islam merupakan industri mulia (noble industry); gabungan dari lembaga yang bersifat profit seperti industri, perusahaan dan jasa dengan nonprofit seperti lembaga dakwah, sosial kemasyarakatan dan lembaga nirbala lainya. Oleh karena itu dari aspek kelembagaan, kepemimpinan spiritual sangatlah cocok guna memimpin lembaga pendidikan. Pemimpin spiritual mampu memerankan diri sebagai corporate, entrepreneur dan businessman atau pebisnis yang professional sehingga mampu mengelola budaya yang efektif dalam proses organisasi dan mengembangkan usaha dengan baik. Di sisi lain, pemimpin spiritual juga harus bisa berperan sebagai tokoh ruhaniawan, pergerakan, relawan dan volunterr yang cerdas dalam menarik simpati dan mengerakkan massa, tokoh spiritual dan seorang pekerja sosial. Oleh karena itu, lembaga pendidikan yang mempunyai dimensi sebagai organisasi profit, organisasi sosial dan dakwah sangat tepat dipimpin oleh orang yang mengembangkan kepemimpinnan spiritual.

2. Sebagai Pembaharu

Puncak dari berhasilnya pemimpin spiritual dalam mengembangkan pendidikan Islam tidak terlepas oleh peranya sebagai pembaharu. Ide-ide atau gagasan-gagasan selalu keluar dari hasil analisis, kontemplasi dan pengembaraan intelektualitas yang luas.

3. Pemimpin spiritual sebagai administrator proses pembelajaran

Selema ini kepala sekolah lebih banyak berperan hanya sebagai administrator pembelajaran.

Tugas seakan sudah maksimal apabila proses pembelajaran dapat berlangsung dengan tertip dan lancar. Pemimpin spiritual memandang tugas sebagai administrator sebagai tugas rutin dan oleh karena itu diserahkan pelaksanaanya kepada masing-masing pimpinan bidang atau unit. Ini tidak berarti tugas sebagai administrator tidak begitu penting, melainkan secara organisatoris telah ada pembagian tugas dan sekaligus sebagai bentuk pengkaderan. Posisi pemimpin spiritual dalam hal ini berperan sebagai pencerah, pengilham dan pembangkit.

\footnotetext{
${ }^{41}$ Sukarji \& Umiarso, Manajemen dalam Pendidikan Islam: Konstruksi Teoritis Filosofis dalam Menemukan Kebermaknaan Pengelolaan Pendidikan Islam, (Jakarta: Mitra Wacana Media, 2014)

42 Tobroni, T. (2015). Spiritual Leadership: A Solution of the Leadership Crisis in Islamic Education in Indonesia. British Journal of Education, 3(11), 40-53.
} 
4. Pemimpin spiritual sebagai pendidik

Salah satu kekuatan yang menyebabkan pemimpin spiritual berhasil dalam mengembangkan pendidikan adalah karena peranya sebagai pendidik (murabbi). Di depan muridnya ia tetap sebagai guru yang peduli sehingga memiliki hubungan yang dekat, akrab, harmoni, dan khurmah. Di depan karyawan dan guru lainya ia adalah seorang teman sesama guru yang senasip dan seperjuangan. Namun dalam pemimpin yang spiritual ini tidak hanya mendidik muridnya tetapi juga bawahannya. Guna untuk memperbaiki kinerja bersama-sama dalam tujuan yang diinginkan bersama. Sehingga kebermanfaatan dalam proses kinerja pun dapat dirasakan bersama.

\section{KESIMPULAN}

Untuk mambangun, mengelola, dan memperkuat sistem pendidikan yang mampu mengahasilkan output pendidikan yang sesuai dengan idealitas, maka tidak bisa lepas dari suatu tatanan filosofis yang melatarinya terutama pada kerangka epistemologinya. Dengan demikian, perlu konstruks epistemologi kepemimpinan dalam pendidikan Islam yang kemudian bermuara pada pengelolaan pendidikan Islam - manajemen- yang dimana suatu tata pengelolaan pendidikan Islam yang didalamnya terdapat sesok pemimpin spiritual.

Substansi kepemipinan spiritual guna mengaktualisasikannya dalam proses transformasi sistem ke ranah yang lebih baik dengan berperan membangun potensi sumber daya manusia (libarasi) melawati perilaku alturistik (humanisasi) guna meraih tujuan duniawi dan ukrawi atas dasar kesadaran ketuhanan (transendensi). Proses tersebut akan melahirkan output yang tidak hanya bersifat rasional (dimensi duniawi), tetapi diorientasikan membangun kelembagaan professional melalui sumber daya manusia yang memiliki kesadaran ketuhanan (dimensi ukhrawi atau transendental) guna mencapai kesempurnaan dunia dan akhirat.

Lembaga pendidikan Islam akan kuat, besar dan dapat bersaing apabila fundamen dalam pengelolaanya mengikuti petunjuk-petunjuk yang ada didalam al-Qur'an dan Hadist. Dengan kata lain, dua dasar ini (Islam) menjadi dasar utama dan nilai operatif dalam pengelolaan lembaga pendidikan yang mulai dari fungsi peramalan (futuristik), perencanaan, pengorganisasian, pengaktualisasian, dan pengawasan hingga pada fungsi evaluasinya atau fungsi tersebut jika dirubah sedemikian mungkin (disederhanakan) dan lazim dikaji menjadi fungsi perencanaan (planning), pengorganisasian (organizing), penggerakan (actuatiang) dan pengawasan (controling).

\section{DAFTAR PUSTAKA}

Agustian. A G. (2001). ESQ Emotional Spiritual Quotient. Jakarta: Arga. Al-Raghib al-Ashfahani. (1992). Mufradat Alfaz al-Qur'an. Damsyiq: Dar al-Qalam. 
Arief, Syamsuddin. (2009). Artikel Seminar Epistemologi Islam Mahasiswa Universitas Gadjah Mada tahun 2009.

Azra. Azumardi. (2000). Pendidikan Islam, Tradisi dan Modernisasi Menuju Milenium Baru. Jakarta: Logos.

(1998). Esei-Esei Intelektual Muslim dan Pendidikan Islam. Jakarta: Logos Wacana Ilmu.

, (1998). "Rekonstruksi Kritis Ilmu dan Pendidikan Islam" dalam M. Anis, at. al. (peny), Reliugilitas Iptek: Rekonstruksi Pendidkan dan Tradisi Pesantren. Yogyakarta: Pustaka Pelajar.

, 1994. Tafsir dalam, Ilmu Pendidikan Dalam Perspektif Islam. Bandung: Remaja Rosda Karya.

Baharuddin \& Umiarso. (2012). Kepemimpinan Pendidikan Islam. Yogjakarta: Ar-Ruzz Media

Bennis, Warren. (1994). On Becoming a Leader. New York: Addison

Covey, Stephen R, The $8^{\text {th }}$ Habit from Effectiveness to Greatness. London: Simon \& Schuster UK Ltd.

Edmonds. R. (1979). Some School Work and More Can, dalam Social Policy, 9 (2).

Goleman. D, (2003). Working with Emotional Intelligence, Kecerdasan Emosi Untuk Mencapai Puncak Prestasi. Jakarta: Gramedia.

Hallinger F.\& Leithwood K. (1994). Introduktion: Exploring the Impact of Principal Leadership. School Effectiveness and School Improvement.

Hart, M.H. (1994). Seratus Tokoh yang Paling Berpengaruh dalam sejarah. Jakarta: Pustaka Jaya.

Ilyasin, M. (2016). Epistemologi Pendidikan Islam Monokotomik: Menakar Manajemen Pendidikan Paripurna Berbasis Rasionalistik Wahyuistik. At-turas: Jurnal Studi Keislaman, 3(1). DOI: https://doi.org/10.33650/at-turas.v3i1.183

Ismail, S. H. (2015). Pembangunan Insan dalam Falsafah Pendidikan Kebangsaan (Human Development in National Education Philosophy). Journal of Human Capital Development (JHCD), 8(2), 83-100.

Khojir, K. (2011). Membangun Paradigma Ilmu Pendidikan Islam: Kajian Ontologi, Epistemologi dan Aksiologi. Dinamika Ilmu, 11(1). DOI: https://doi.org/10.21093/di.v11i1.51

Mahmud, M. E. (2012). Motif Penyelenggaraan Pendidikan Islam dan Implikasinya pada Pola Manajemen dan Kepemimpinan. Dinamika Ilmu, 12(2). DOI: https://doi.org/10.21093/di.v12i2.60

Maya, R., \& Lesmana, I. (2018). Pemikiran Prof. Dr. Mujamil Qomar, M. Ag. tentang Manajemen Pendidikan Islam. Islamic Management: Jurnal Manajemen Pendidikan Islam, 1(02), 291316. DOI: http://dx.doi.org/10.30868/im.v1i2.281

Minarti, Sri. (2013). Ilmu Pendidikan Islam: Fakta Teoritis-Normatif \& Aplikatif-Normatif. Jakarta: Amzah. 
Muhammad Syafi'i Antonio. (2007). Muhammad Saw: The Super Leader Super Manager. Jakarta: PLM.

Musa Asy'ari. (2001). Filsafat Islam: Sunnah Nabi dalam Berfikir. Yogyakarta: LEFSi.

Noor Hamid dan Muhammad Iqbal Juliansyahzen. (2017). "Prophetic Leadership in Pesantren Education: Study at Pondok Pesantren Universitas Islam Indonesia," Jurnal Pendidikan Islam 6, no. 2. DOI: https://doi.org/10.14421/jpi.2017.62.349-369

Novitasari, N., \& Nurani, F. Pemimpin Yang Bersumber Dari Keturunan.

Oxford. (1995). Advanced Learners's Dictionary. Oxford Universuity Press

Pramitha, D. (2016). Kajian Tematis Al-Qur'an Dan Hadits Tentang Kepemimpinan. J-PAI: Jurnal Pendidikan Agama Islam, 3(1). DOI: http://dx.doi.org/10.18860/jpai.v3i1.3989

Qomar, M. (2013). Strategi Pendidikan Islam. Jakarta: Erlangga.

Quthb, Sayyid. Fi Zilal al-Qur'an, Jilid I. Kairo: Dar al-Syuruq, Cet. XVIII, 1412 H/ 1992 M.

Robert Audy. (2011). Epistemology: A Contemporary Introduction to the Theory of Knowledge. London: Routledge.

Sahih Al-Bukhari dari Ibnu Umar ra No. 893,2409, 2558, 2751, 5188, 5200 dan Sahih Muslim dari Ibnu Umar ra No. 4724. HR. Tirmidzi: bab al-Jihad. HR. Abu Dawud: bab al-Imarat dan HR. Ahmad: bab al-Imam. Baca: Almaktabah Shamillah Bahsun fi Nusus.

Santrock, John W. (2003). Adolescence. Perkembangan Remaja. Edisi Keenam. Jakarta: Erlangga.

Sarwono, Sarlito W. \& Eko A. Meinarno. (2009). Psikologi Sosial. Jakarta: Penerbit Salemba Humanika.

Sayyi, A. (2017). Modernisasi Kurikulum Pendidikan Islam Dalam Perspektif Azyumardi $\begin{array}{llll}\text { Azra. TADRIS: } & \text { Jurnal }\end{array}$ DOI: http://dx.doi.org/10.19105/tadris.v12i1.1285

Sukarji \& Umiarso. (2014). Manajemen dalam Pendidikan Islam: Konstruksi Teoritis Filosofis dalam Menemukan Kebermaknaan Pengelolaan Pendidikan Islam. Jakarta: Mitra Wacana Media.

Tafsir, Ahmad. (2001). Filsafat Umum: Akal Dan Hati Sejak Thales Sampai Capra. Bandung: Remaja Rosdakarya.

Taimiyah, Ibnu. (1967). Pedoman Islam dalam Beragama. Bandung: CV. Diponegoro.

Taufiq, Imam. (2016). Al-Qur'an Bukan Kitab Teror: Membangun Perdamaian Berbasis alQur'an. Yogyakarta: Bentang.

Tobroni, T. (2015). Spiritual Leadership: A Solution of the Leadership Crisis in Islamic Education in Indonesia. British Journal of Education, 3(11), 40-53.

Umiarso, U. (2018). Kepemimpinan Transformasional Profetik dalam Mengembangkan Pesantren Di Kabupaten Jember. Akademika: Jurnal Pemikiran Islam, 23(1), 87-106. DOI: https://doi.org/10.32332/akademika.v23i1.1205 